\title{
Comparative Study of Nutrients and Anti-Nutrients Composition of Commonly Consumed Edible Grasshopper (Chorthippus brunneus), Locust Beans (Parkia Biglobosa) and Soya Beans (Glycine max) in Katsina State
}

\author{
*1Abubakar, M., and ${ }^{1,2}$ Abdullahi, N. \\ ${ }^{1}$ Department of Biological Sciences, Al-Qalam University Katsina.P.M.B 2137, Katsina State, Nigeria, \\ ${ }^{2}$ Department of Biochemistry, Bayero University, Kano, Nigeria \\ *Corresponding Author: abubakarmusa457@gmail.com and +2347038125505.
}

Abstract
The purpose of this study is to evaluate the nutrients, anti-nutrients and minerals composition of
edible grasshopper (Chorthippus brunneus), locus beans and soya beans. The evaluations of
nutrients and anti-nutrient composition of Chorthippus brunneus, Parkia biglobosa and Glycine
max were analyzed using standard methods of A.O.A.C. and Kjedahal methods. The proximate
analysis revealed that crude protein ranged between $24.667 \pm 3.512$ to $39.561 \pm 2.553$ with
Chorthippus brunneus having the highest value and Parkia biglobosa and Glycine max having the
lowest values. The Chorthippus brunneus had a considerable low carbohydrate contents
compared to P. biglobosa and $G$. max carbohydrate value. However, the mean energy/caloric
values ranged from 474 to 522 Kcal/Kg. Crude fat values were moderate, ranging from
$11.763 \pm 1.035$ to $15.26 \pm 0.761$ with G. max having the highest value and C. brunneus the lowest.
The anti-nutrients of the insects and the legumes were generally below toxic level in man.
Moisture, ash and crude fibre were very high in C. brunneus compared to Parkia biglobosa and
Glycine max. These Chorthippus brunneus therefore, could serve as additional promising sources
of protein and fat for poultry and teeming population. The mineral compositions of the inscts
(mg/kg) were considerably lower than that of locus beans and soya beans.
Key: Chorthippus brunneus, Glycine max, Nutritional composition, Parkia biglobosa,

\section{INTRODUCTION}

The rapid growth of the world population requires proportionate increases in food production. However, it is difficult to increase productivity to a level that satisfies food demand, mainly because of limited availability of new farm land (DeFoliart, 2002; Verkerk et al., 2007) This has led to shortage of food particularly animal protein. Therefore, it has become essential to look for new sources of animal protein. Some food resources which were neglected like edible insects are reemerging and information about their nutritive values is becoming significant. Insects have played an important part in the history of human nutrition in Africa, Asia and Latin America (Ramos-Elorduy et al.,1997; Kampmeier, and Irwin, 2009).

In Katsina State of Nigeria, insects have been part of the cultural diet for many decades. During the past few years there has been renewed global interest in insects as food and an estimated 2,000 insects species are consumed around the world (Odaibo, 2009). Many insects such as Grasshopper (Chorthippus brunneus), locusts and termites are still being enjoyed as delicacies in many part of Nigeria, particularly in the rural areas of Katsina State (Odaibo, 2009).

According to Owen (1973), insects are sources of many different minerals and essential proteins. Since insect reproduce very fast and very easily, they can, therefore contribute to meeting protein needs of rural populace, and thus be considered as an alternative in efforts to increase food security for poor nation. The high fat and protein content of insects make them an ideal food additive for chiefly carbohydrate diets. The collection of edible insects is also a good source of income especially for women in rural areas of Katsina state and may serve as a biological pest control, safeguarding forest habitat, prevent erosion, preserves water source and protects countless other forest species.

The high cost of animal protein has greatly affected malnutrition in our society. Therefore, edible insect such as grasshopper can serve as an animal substitute for protein production. 


\section{UJMR, Volume 6 Number 2, December, 2021, pp 59 - 64 ISSN: 2616 - 0668}

Since these sources have been utilized by the populace, this study was aimed at evaluating the nutrient composition as well as antinutrient composition and mineral element of grasshopper which is usually consumed across the State and compared it with Locus beans and Soya beans.

\section{MATERIALS AND METHODS}

\section{Study Area}

The study was conducted between January to August, 2020 in Katsina the capital town of Katsina State, Nigeria. Katsina city is located on coordinates $12^{\circ}, 15^{\circ}$ North and $7^{\circ}$ to $30^{\circ}$ East, with a total population of 5,801, 584 (National Population Commission, 2006) and covers an area of $24,192 \mathrm{~km}^{2}$ with an elevation of $519 \mathrm{~m}$ above sea level. It has with an international boundary in the north to Niger republic, it also shares border in the east with Kano and Jigawa state, in the west with Zamfara state and in the south with Kaduna state.

\section{Sample Collection}

The dried sample of grasshopper was purchased from Chake market (Himata) in Katsina Local Government area of Katsina State, Nigeria. It was then taken to the Biological Science laboratory, Al-qalam University Katsina, Nigeria for analysis.

Preparation

The dried sample was ground into powder using motor and pestle for proximate and minerals analysis.

Determination of Moisture Content

Six (6) gram of the grinded sample was weighed into a previously weighed crucible. The crucible was then placed in hot-oven set at $100^{\circ} \mathrm{C}$ to dry to a constant weight for $24 \mathrm{~h}$. The crucible was removed from the oven and transferred to desiccator, cooled for ten minutes and weighed. The same procedure was repeated until constant weight was obtained. The moisture content was then calculated as percentage moisture according to the methods of (Owoso and Ogunmoyela, 2001).

The percentage is obtained by the formula:

$$
\% \text { Moisture }=\frac{W 2-W 3}{W 2-W 1} \times 100
$$

Determination of Crude Fat

Crude fat was quantified according to AOAC (1999; No. 920.85) method. Extraction of fat was done with soxhlet extracting machine (HT 1043 extraction unit, Tecator, Hoganas, Sweden), using petroleum ether (40-60 boiling points) as the extractor. A $250 \mathrm{ml}$ extraction flask was washed and dried in an oven at $105^{\circ} \mathrm{C}$, and weighed. $30 \mathrm{~g}$ of the ground sample was weighed into a labeled porous thimble. The thimble mouth was covered with white clean cotton wool. $200 \mathrm{ml}$ of petroleum ether was added into $250 \mathrm{ml}$ extraction flask. The covered porous thimble was placed into the condenser and the apparatus was assembled for extraction, which continues for 6hrs. The porous thimble was removed and the extraction flask was placed on the water bath to make it free from petroleum ether. The weight was taken as (W3). Percentage fat was calculated as follows:

$$
\% \text { Fat }=\frac{W 3-W 2}{W 1-W 0} X 100
$$

Where: W0 $=$ Weight of empty porous thimble, $W 1$ = Weight of thimble + ground sample, $W 1$ W0 $=$ Weight of ground sample, W2 = Weight of empty extraction flask, W3 = Weight of extraction flask + oil

\section{Determination of Ash Content}

Ten (10) grams of the sample was weighed into a porcelain crucible. This was transferred into the muffle furnace set at $550{ }^{\circ} \mathrm{C}$ and left for $1 \mathrm{~h}$. after which the sample was removed and placed in a desiccator containing silica gel. The percentage ash was then calculated according to the methods of Udo and Ogunwale (1986).

$$
\% A s h=\frac{W 3-W 1}{W 2-W 1} X 100
$$

\section{Determination of Protein Content}

Concentrated sulphuric acid $(20 \mathrm{ml})$ was introduced into the micro-Kjeldahl flask containing $2 \mathrm{~g}$ of ground sample. Two Kjeldahl catalyst tablets were added and digested for 4 $\mathrm{h}$, cool overnight in a fume cupboard and the contents diluted with water to $250 \mathrm{~cm}$. A distillation unit was then used and the percentage nitrogen determined according to the Kjeldahl techniques of the (AOAC,1990).

$\%$ Nitrogen $=\frac{\text { NA } X \text { TV } X 0.014 X \text { D.F }}{\text { Volume of aliquot } X \text { weight of sample }} X 100$ Where; NA $=$ Normality of acid $(0.01 \mathrm{~N}), T V=$ Titer value, $\mathrm{DF}=$ Dilution Factor, Volume of aliquot $=10 \mathrm{ml}$

Determination of Carbohydrate (CHO)

Two (2) grams of the samples were collected and dried in the oven at $70^{\circ} \mathrm{C}$, of ground and defatted. The soluble sugars were extracted with $80 \%$ ethanol $(\mathrm{v} / \mathrm{v})$ following the methods of Omafuvbe et al. (2004). The total soluble sugar was determined by the anthrone reagent method of Morris (1948) and reducing sugar was determined by the calorimetric method (Somogyi, 1945) using standard curve of glucose. 
UJMR, Volume 6 Number 2, December, 2021, pp 59 - 64 ISSN: 2616 - 0668

\section{Determination of Crude Fibre}

Two (2) grams of the sample were ground and diluted in $100 \mathrm{ml}$ distilled water in a conical flask. $20 \mathrm{ml}$ of $10 \%$ sulphuric acid were added and boiled gently for $30 \mathrm{~min}$. The sample was then cooled and filtered. The filtrate was subjected to treatment using $10 \%$ sodium hydroxide. The residue was passed through 20 $\mathrm{ml}$ of ethanol and petroleum ether and then dried at $105 \mathrm{C}$. The sample was weighed and ashed at $0100 \mathrm{C}$ for $90 \mathrm{~min}$ cooled and reweighed and the o percentage of crude fibre calculated (Owoso et al., 2000).

$$
\% \text { Fibre } \frac{W 2-W 3}{W 1} \times 100
$$

\section{Determination of Free Fatty Acid}

The extracted oil $(0.1 \mathrm{~g})$ was weighed into a clean dry conical flask; then $10 \mathrm{ml}$ of $95 \%$ Ethanol and $1 \mathrm{~cm} 3$ of phenolphthalein indicator were added. This was then titrated with $0.1 \mathrm{~m}$ $\mathrm{NaOH}$, with constant shaking until a pink colour persisted for 30 minutes

$$
\% F F A=\frac{V X M X 2.82}{W}
$$

Where; FFA = Free Fatty Acid, $\mathrm{V}=$ Titer value, $\mathrm{W}=$ Weight of the sample

\section{Determination of Phytate Content}

Four (4) grams of the sample was soaked in $100 \mathrm{ml}$ of $2 \% \mathrm{HCl}$ for 5 hours and then filtered. A portion $(25 \mathrm{ml})$ of the filtrate was taken into the conical flask and $5.0 \mathrm{ml}$ of $0.3 \% \mathrm{NH}_{4} \mathrm{SCN}$ solution was titrated with a standard solution of $\mathrm{FeCl}_{2}$ containing $0.00195 \mathrm{~g} \mathrm{Fe} / \mathrm{ml}$ until a brownish yellow colour persisted for 5 minutes. $1 \mathrm{ml}=1.10 \mathrm{mg}$ Phytin-Phorsphorus. The phytate content was calculated by multiplying the value of Phytin-Phosphorus by 3.55.

$$
\text { Conc. of phytate }(\mathrm{mg} / 100 \mathrm{~g})=\frac{\text { TVXEqv.Wt X D.F X } 3.55 \times 1000}{W}
$$

$\mathrm{TV}=$ titre value, Eqv. $\mathrm{Wt}=$ equivalent weight, D. $F=$ dilution factor, $1000=$ conversion factor to $\mathrm{mg} / 100 \mathrm{~g}$ of sample and $\mathrm{W}=$ weight of sample

\section{Determination of Oxalate Content}

A quantity $(2.5 \mathrm{~g})$ of the sample was extracted with $100 \mathrm{ml}$ of $2 \% \mathrm{HCl}, 5 \mathrm{ml}$ of conc. $\mathrm{NH}_{3}$ and precipitated with $\mathrm{CaCl}_{3}$ as calcium oxalate. The precipitate was then washed with $20 \mathrm{ml}$ of $25 \%$ $\mathrm{H}_{2} \mathrm{O}_{4}$ and dissolved in hot water, and then titrated with $0.05 \mathrm{~N} \mathrm{KMnO}_{4}$ to determine the conc. of oxalate until a pink end point was observed. $\left(1 \mathrm{ml}\right.$ of $0.05 \mathrm{~N} \mathrm{KMnO}_{4}=0.045 \mathrm{~g}$ oxalic acid)
Conc. of oxalate $(\mathrm{mg} / 100 \mathrm{~g})=\frac{\text { TVXEqv.Wt } X \text { D.F } X 3.55 \times 1000}{W}$

$\mathrm{TV}=$ Titre Value, Eqv. Wt $=$ Equivalent Weight, D.F = Dilution Factor, $3.55=$ Phytin-Phosphorus Factor, $1000=$ Conversion Factor to $\mathrm{mg} / 100 \mathrm{~g}$ of sample and $\mathrm{W}=$ Weight of Sample

\section{Determination of Tannin Content}

Sample (0.5gram) was weighed into a plastic bottle. $100 \mathrm{ml}$ of distilled water was added and shaken for $1 \mathrm{hr}$ in a mechanical shaker. This was filtered into $10 \mathrm{ml}$ volumetric flask and made up to the mark then $1 \mathrm{ml}$ of the filtrate was pipetted into test-tube and mixed with $0.4 \mathrm{ml}$ of $0.1 \mathrm{M} \mathrm{FeCl} 2$ in $0.1 \mathrm{~N} \mathrm{HCl}$ and $0.008 \mathrm{M}$ potassium ferrocyanide. The absorbance was measured at 550nm within 10 minutes.

Conc. of tannin $\left(\frac{m g}{100 g}\right) C u=\frac{A u}{A S} X \operatorname{CS} X 1000$

$\mathrm{AU}=$ absorbance of unknown sample, $\mathrm{AS}=$ absorbance of standard, CS = concentration of standard, $\mathrm{CU}=$ concentration of unknown sample and $1000=$ conversion factor to $\mathrm{mg} / 100 \mathrm{~g}$.

\section{Analyses of Some Mineral Composition}

One gram of sample was weighed into a crucible, burned on hot plate until the smoke subsides completely and then made to ash in a muffle furnace at $500^{\circ} \mathrm{C}$ for 6 hours. The crucible was transferred into a desiccator and allowed to cool. The ash sample was dissolved in $1 \mathrm{ml}$ of concentrated nitric acid. The dissolved ash sample was evaporated to dryness on a hot plate. $5 \mathrm{ml}$ of $5 \mathrm{M}$ hydrochloric acid was added and transferred to $100 \mathrm{ml}$ standard volumetric flask. It was then made up to mark with distilled water and filtered. The prepared sample was analyzed for the mineral elements ( $\mathrm{Zn}, \mathrm{Fe}, \mathrm{Ca}, \mathrm{Mn}, \mathrm{Na}, \mathrm{K}$ and $\mathrm{Cu}$ ) using Atomic Absorption Spectrophotometry.

\section{Data Analysis}

Data on the nutritional composition of the different insect species were analyzed using Sigma Stat 3.5 analytical software. Analysis of Variance (ANOVA) was performed and differences between means were separated using Least Significant Difference (LSD) test at $5 \%(P<0.05)$ level of significance. Results were reported as means \pm standard deviations.

\section{RESULTS AND DISCUSSION}

All the samples have significantly different nutritional composition except the protein contents of Glycine max and Chorthippus brunneus which are not significantly different 


\section{UJMR, Volume 6 Number 2, December, 2021, pp 59 - 64 ISSN: 2616 - 0668}

at the $5 \%$ level. This similarity in protein content may be due to high consumption of various dietary protein foods by the Chorthippus brunneus. The Chorthippus brunneus has the highest amount of moisture while the Parkia biglobosa and Glycine max have the lowest moisture content as show in (table 1.0). The results obtained for the proximate composition of Chorthippus brunneus, Parkia biglobosa and Glycine max are somewhat different from what was previously reported by (Aduku, 1993), (Melik, 1969 and Bedford, 1980).

The high moisture content in the Chorthippus brunneus implies that it cannot be stored for a very long time since moisture which is an important medium for multiplication of microorganisms is very high in Chorthippus brunneus sample. The high ash content is indicative that the Chorthippus brunneus could be important sources of minerals, compared to lower ash contents of Parkia biglobosa and Glycine max. The high protein content of $39.561 \pm 2.553$ of the Chorthippus brunneus suggests that it could be used in the management of protein deficiency cases such as Kwashiorkor, compared to lower protein for Parkia biglobosa. The lower crude fat content suggests that the Chorthippus brunneus may not be a viable source of oil, going by their crude fat contents when compare to high crude fat observed in Parkia biglobosa and Glycine max as show in (table 1.0).

The Chorthippus brunneus, Parkia biglobosa and Glycine max samples contained relatively low fibres, but the presence of fibre in foods is known to be beneficial. Fibre has some physiological effects in the gastrointestinal, tract. These effects include variation in faecal water, faecal bulk and transit time and elimination of bile acids and neutral steroids which lower the body cholesterol pool (Aduku, 1993).

The carbohydrate contents in the Chorthippus brunneus is relatively high but lower than what was obtained in Parkia biglobosa and Glycine max. This suggests that the insect could be used in managing protein-energy malnutrition since there is enough quantity of carbohydrate to derive energy from in order to spare protein so that protein can be used for its primary function of building the body and repairing worn out tissues rather than as a source of energy (Melik, 1969 and Bedford, 1980).

The study revealed that the insect under study have high nutritional qualities. The protein content of the insect has been studied and compared with the protein content of Locus beans and Soya beans. The result of the proximate analysis of Chorthippus brunneus from this study is similar to that obtained by others (Aduku, 1993; Melik, 1969; Bedford 1980). However, the value of proximate analysis of glycine max and Parkia biglobosa were lower than that of Chorthippus brunneus. These differences may be due to high consumption of various dietary foods by the insect. The results of this study also confirm the fact that insects are indeed a good source of protein and other nutrients. The consumption of non-toxic insect should therefore be encouraging.

TABLE 1: Proximate Composition of Chorthippus brunneus, Parkia biglobosa and Glycine max

\begin{tabular}{llll}
\hline Parameters (\%) & C. brunneus & P. biglobosa & G. max \\
\hline Crude Protein & $39.561 \pm 2.553^{\mathrm{b}}$ & $24.667 \pm 3.512^{\mathrm{a}}$ & $38.333 \pm 6.807^{\mathrm{b}}$ \\
Crude Fat & $11.763 \pm 1.035^{\mathrm{b}}$ & $13.68 \pm 3.257^{\mathrm{a}}$ & $15.26 \pm 0.761^{\mathrm{a}}$ \\
Crude Fibre & $4.703 \pm 1.535^{\mathrm{a}}$ & $3.175 \pm 0.209^{\mathrm{a}}$ & $2.953 \pm 0.0971^{\mathrm{a}}$ \\
Ash content & $6.607 \pm 0.930^{\mathrm{b}}$ & $2.96 \pm 0.286^{\mathrm{a}}$ & $3.773 \pm 0.448^{\mathrm{a}}$ \\
Moisture Content & $11.00 \pm 0.600^{\mathrm{c}}$ & $4.363 \pm 0.342^{\mathrm{a}}$ & $8.547 \pm 1.005^{\mathrm{b}}$ \\
Carbohydrate & $25.57 \pm 6.606^{\mathrm{b}}$ & $51.962 \pm 7.343^{\mathrm{a}}$ & $29.36 \pm 7.457^{\mathrm{b}}$ \\
\hline
\end{tabular}

Key: Values are means of 3 triplicate determination \pm S.D, means with different superscript along the same horizontal array differ significantly $(P<0.05)$.

The oxalate content recorded was the lowest compared to tannins and phytate. On the other hand, Parkia biglobosa had the least percentage concentration of phytate and oxalate compared to Chorthippus brunneus and glycine max as show in Table 2.0. The concentrations of all the antinutrients in the insect and the legumes happened to be within acceptable levels. 
UJMR, Volume 6 Number 2, December, 2021, pp 59 - $64 \quad$ ISSN: 2616 - 0668 TABLE 2: Anti Nutrient Composition of Chorthippus brunneus, Parkia biglobosa and Glycine $\max (\mathrm{mg} / 100 \mathrm{~g})$

\begin{tabular}{llll}
\hline Parameters & C. brunneus & $P$.biglobosa & G. max \\
\hline Phytate & $0.0247 \pm 0.0025^{\mathrm{b}}$ & $0.0345 \pm 0.0022^{\mathrm{a}}$ & $0.0127 \pm 0.0145^{\mathrm{b}}$ \\
Oxalate & $0.0873 \pm 0.0037^{\mathrm{b}}$ & $0.0433 \pm 0.0065^{\mathrm{a}}$ & $0.0563 \pm 0.0028^{\mathrm{a}}$ \\
Tannin & $0.0971 \pm 0.0027^{\mathrm{c}}$ & $0.0761 \pm 0.0012^{\mathrm{a}}$ & $0.0571 \pm 0.0091^{\mathrm{b}}$ \\
\hline
\end{tabular}

Key: Values are means o 3 triplicate determination \pm S.D, means with different superscript along the same horizontal array differ significantly $(P<0.05)$.

TABLE 3: Mineral Composition of Chorthippus brunneus, Parkia biglobosa and Glycine max $(\mathrm{mg} / 100 \mathrm{~g})$

\begin{tabular}{llll} 
Mineral element & C. brunneus & P. biglobosa & G. max \\
\hline Zinc $(\mathrm{Zn})$ & $1.187 \pm 0.005^{\mathrm{a}}$ & $1.857 \pm 0.0666^{\mathrm{a}}$ & $3.080 \pm 0.0100^{\mathrm{b}}$ \\
Iron $(\mathrm{Fe})$ & $3.43 \pm 0.2140^{\mathrm{c}}$ & $16.247 \pm 0.0577^{\mathrm{a}}$ & $12.41 \pm 0.0529^{\mathrm{b}}$ \\
Calcium $(\mathrm{Ca})$ & $30.97 \pm 0.010^{\mathrm{b}}$ & $3.138 \pm 0.00608^{\mathrm{a}}$ & $2.87 \pm 0.01000^{\mathrm{a}}$ \\
Magnesium $(\mathrm{Mg})$ & $7.997 \pm 1.469^{\mathrm{b}}$ & $11.897 \pm 1.423^{\mathrm{a}}$ & $9.597 \pm 1.289^{\mathrm{a}}$ \\
Manganese $(\mathrm{Mn})$ & $0.533 \pm 0.577^{\mathrm{b}}$ & $0.353 \pm 0.123^{\mathrm{a}}$ & $0.235 \pm 0.201^{\mathrm{a}}$ \\
Sodium $(\mathrm{Na})$ & $89,837 \pm 0.781^{\mathrm{c}}$ & $110.509 \pm 0.149^{\mathrm{a}}$ & $172.837 \pm 0.613^{\mathrm{b}}$ \\
Potassium $(\mathrm{K})$ & $12.893 \pm 0.0232^{\mathrm{b}}$ & $21.66 \pm 0.0954^{\mathrm{a}}$ & $15.763 \pm 0.0862^{\mathrm{b}}$ \\
Copper $(\mathrm{Cu})$ & $0.456+0.00512^{\mathrm{a}}$ & $0.377+0.00577^{\mathrm{a}}$ & $0.887+0.00577^{\mathrm{b}}$ \\
\hline
\end{tabular}

Key: Values are means o 3 triplicate determination \pm S.D, means with different superscript along the same horizontal array differ significantly $(P<0.05)$.

The high calcium content in the insect could be used in complementary foods to help build the bones and teeth since calcium is one of the main components of teeth and bones when compared to low contents in locus beans and soya beans. Calcium also plays a role in blood clotting (Mehas et al., 1997). Magnesium is involved in making proteins and releasing energy and helps hold calcium in the enamel of the teeth.

Iron is used in the management of iron deficiency anaemia since iron is a vital part of red blood cells that carry and release oxygen (Mehas et al., 1997). Phosphorus is closely linked with calcium. The two minerals combine to form calcium phosphate, which gives bones their rigid structure (Mehas et al., 1997). Sodium is needed in the body in a small amount to help maintain normal blood pressure and normal function of muscles and nerves. Zinc helps the immune system fight off invading bacteria and viruses. The body needs zinc to make proteins and DNA, the genetic material in all cells and also helps in wound healing and

REFERENCES

AOAC (2006). Official methods of analysis. 18th ed. Revised. Washington, DC, USA: Association of Official Analytical Chemists.

AOAC, (2005). Official methods of analysis. 18th ed. Revised. Washington, DC, USA: Association of Official Analytical Chemists.

AOAC, (1990). Official methods of analysis of the Association of Official Analytical the breakdown of carbohydrates. Also, zinc is below the permissible level of 50 and $100 \mathrm{mcg} / \mathrm{g}$ in grains and beans (USDA, 2003).

\section{CONCLUSION}

The study has established the proximate nutrients, antinutrients and minerals (calcium, sodium, zinc, magnesium, manganese, potassium, copper, iron and phosphorus) concentrations of Chorthippus brunneus, Parkia biglobosa and Glycine max. The results of this study indicate that the insect is rich in proteins, fats and carbohydrates and are therefore inexpensive source of macronutrients which can be used in intervention programme aimed at alleviating protein-energy malnutrition. The flour from the locus bean and soya bean has good protein contents and could be used to fortify flours with low protein content such as maize and rice. The mineral contents indicate that the flour samples could be important sources of minerals for humans and farm animals and they also contained tolerant level of anti -nutrients.

Chemists.15th ed. U.S.A: Association of Official Analytical Chemists.

DeFoliart, G.R. 2002. The human use of insects as food resource: a bibliographic account in progress, p.1737- 1757. Department of Entomology, University of Wisconsin-Madison: USA.

John (2015) Compositional Studies on edible tropical species of mushrooms. Food Chemistry, 1995, 54:265-268.

Kampmeier, G. E. and Irwin, M. E. 2009. 2nd ed. Commercialization of Insects and 
UJMR, Volume 6 Number 2, December, 2021, pp 59 - $64 \quad$ ISSN: 2616 - 0668

Their Products. In Vincent, H. R. and Ring, T. C. Encyclopedia of Insects, p. 220-227. San Diego: Academic Press.

Mehas KY, Rodgers SL. (1997). Food science. The Biochemistry of Food and Nutrition. 3rd Edition. Glencoe / McGraw-Hill, Peoria. Illinois, U.S.A.;35:169-171.

Ramos-Elorduy, J., Moreno, J. M. P., Prado, E. E., Perez, M. A., Otero, J. L. and De Guevara, O. L. (1997). Nutritional value of edible insects from the state of Oaxaca, Mexico. Journal of Food Composition and Analysis 10(2): 142157.

NJ.Zara,Mogans, J., Protein and Bukken, (2020). Nutrition policy in low income countries. London, UK: Charles Knight Co. Ltd. 1995, Pp 43 - 50

Omafuvbe, O.O., O.S. Falade, B.A. Osuntogun and R.A. Adewusi, (2004). Chemical and biochemical changes in african locust bean (Parkiabiglobosa) and melon (Citrullus vulgaris) seeds during fermentation to condiments. Pak. J. Nutr., 3: 140- 145.

Ogunwale, (1986). Determination of sugars In: Laboratory Manual for the analysis of soil, water and plant samples (2nd Ed) Lagos, Nigeria

Oyewole, O.B. and S.A. Odunfa, (1990). Effect of cooking method on water absorption and ease of dehulling in preparation of African locust beans for iru. Int. J. Food Sci. Tec., 25: 461-463.

Owoso, O., O. Aluko and O.I. Banjoko, (2000). Quantitative Analysis of Food. In: Manual of Food Analysis and Quality Control. Concept Publications, Lagos Nigeria.

Owoso, O. and O.A. Ogunmoyela, (2001). Proximate Constituents of Food. In: Chemical Analysis of Foods- an outline. Concept Publishers Limited, Lagos Nigeria.

Somogyi, M., (1945). A new reagent for the determination of sugars. J. Biol. Chem., 160: 61-68.

Udo, E.J. and J.A. Ogunwale, (1986). Determination of sugars In: Laboratory Manual for the analysis of soil, water and plant samples (2nd Ed) Lagos, Nigeria.

USDA.(2003). Zinc in foods-draft for comments. Foreign Agricultural Service (GAIN Report) CH 3043. China. People Republic of FAIRS. Products Specific MRL.

Verkerk, M., Tramper, J., Van Trijp, J. and Martens, D. 2007. Insect cells for human food. Biotechnology Advances 25(2):198-202. 